\title{
WANPRESTASI PERJANJIAN RUMAH TOKO DI JALAN \\ SIDOMULYO NOMOR 4 KECAMATAN NANGA \\ PINOH KABUPATEN MELAWI
}

\author{
Stefanus Ngebi \\ Fakultas Hukum Universitas Kapuas Sintang \\ Jalan YC. Oevang Oeray 92 Sintang \\ Email : stefanus_ngebi007@yahoo.co.id
}

terms one of the parties defaults on the lease

\begin{abstract}
In steering a cooperative-work or business affiliation in the field of lease a building, whereas for the case of this research is a house store, it is certainly every single business actor should create rules of the game as outlined in the form of an agreement between the parties covered in order to evade legal problems that occur in the future. The parties must construct an agreement used as a legal base which obeyed by the parties covered. The approach used in this research is a Sociological Juridical Method. The approach is defined as problem analysis through legal research of factual facts in institution concerned or toward the community which covered as problems handled in the research. This research is designed in form of descriptive analysis which identifies the whole systematic object of the research problem. Furthermore, if the agreement that have been agreed upon by the parties concerned are not properly applied, as a consequences one of the parties can prosecute for compensation due to carelessness or it may also clarify in legal
\end{abstract}

agreements that have been mutually approved. As result, In the implementation of the rental agreement of rent a house store between a lessor and the lessee on Sido Mulyo avenue, Nanga Pinoh District, Melawi Regency, itis implemented properly with the phases accomplish by the parties as follows: arising fromnegotiationstosigningtheleaseagreement letter and it should be as responsibilities of the all parties in accomplishing it properly as decided on the the agrreement of rent a house store on the sidomulyo avenue, Nanga pinoh district, Melawi regency. Moreover, in each cancellation of the agreement, all the risk of the lease will be as a responsibility of the lessee if it is canceled. Thus, the agreement must be implemented in good trust on the rights and obligations attached for eachparty. It also the contents of the agreementmust be regulated complete with presence of sanctions. If there is negligence in adhering to the contents of the agreement, a legal formal should provide an appropriate settlement. Along with it, the design of the contents of the 

agreement is accomplished in a meticulous and decisive. Thus, the responsibilities of the parties toward the rights and obligations of each party immediately accomplished.

\section{Keywords: Default, rental agreement of house store.}

\section{ABSTRAK}

Dalam melakukan hubungan kerja sama atau bisnis di bidang perjasaan sewa menyewa bangunan dalam hal ini Rumah Toko (Ruko) tentu untuk menghindari masalah-masalah hukum yang terjadai dikemudian hari setiap pelaku usaha sudah sepatutnya membuat aturan main yang dituangkan dalam bentuk perjanjian antara pihak-pihak yang berkepentingan. Pihakpihak yang berkepentingan harus membuat suatu kesepakatan yang akan dijadikan dasar hukum dan akan di taati oleh pihak-pihak yang membuatnya. Dalam penelitian ini adalah Metode Yuridis Sosiologis yaitu pendekatan masalah melalui penelitian hukum dengan fakta yang ada pada instansi yang bersangkutan ataupun masyarakat sehubungan dengan permasalahan yang ditemui dalam penelitian . Sifat penelitian ini adalah Deskriptif Analisis, yaitu suatu penelitian yang menggambarkan secara menyeluruh dari sistematis obyek dari pokok permasalahan. Konsekuensi dari isi- isi perjanjian yang telah disepakati oleh pihakpihak bersangkutan, jika tidak dilaksanakan sebagaimana mestinya, maka salah satu pihak dapat menuntut ganti rugi akibat kelalaianatau dalam istilah hukum salah satu pihak melakukan wanprestasi terhadap perjanjianperjanjian yang telah di sepakati bersama tersebut.

Dalam pelaksanaan perjanjian sewa menyewa rumah toko antara yang menyewakan dengan pihak penyewa di Jalan Sido Mulyo Kecamatan Nanga Pinoh Kabupaten Melawi telah dilaksanakan sesuai dengan tahapantahapan yang dilakukan oleh para pihak mulai dari negosiasi sampai dengan penandatangan surat perjanjian dan bahwa tanggungjawab bagi para pihak dalam melaksankan perjanjian sesuai dengan kesepakatan yang dilaksanakan sewa menyewa rumah toko dijalan Sidomulyo Kecamatan Nanga pinoh kabupaten Melawi dalam setiap pembatalan perjanjian maka resiko dari sewa menyewa tersdebut menjadi tanggung jawab si penyewa apabila dibatalkan. Selayaknya perjanjian itu dilakukan dengan itikat baik berdasarkan hak dan kewajiban yang melekat pada masing-masing pihak serta dalam isi perjanjian diatur terlebih dahulu serta ikutsertakan sanksi dari masing-masing pihak jika terjadi kelalaian dalam menepati isi perjanjian secara legal formal memberikan kemudahan dalam penyelesaiannya. Sselain itu diharapkan agar perumusan isi perjanjian dilakukan secara rinci dan tegas sehingga tanggung jawab para pihak dalam memenuhi hak dan kewajiban masing-masing pihak 
dapat dengan segera terpenuhi.

Kata kunci : Wanprestasi, perjanjian sewa menyewa Rumah Toko.

\section{PENDAHULUAN}

Pembangunan di bidang ekonomi membawa pengaruh terhadap pembangunan sosial manusia dan perekonomian masyarakat, termasuk pembangun di sektor perumahan dan jasa, dengan adanya pergerakan bisnis masyarakat tidak terlepas dari meningkatnya kebutuhan masyarakat terhadap kebutuhan khususnya barang-barang sebagai salah satu sarana untuk meningkatkan kesejahteraan taraf hidup, serta masyarakat yang mencari kepuasan untuk memenuhi kebutuhan.

Manusia sebagai salah satu mahluk ciptaan Tuhan Yang Maha Esa, diberi kebebasan untuk melakukan kegiatan-kegiatan berdasarkan ketentuan-ketentuan peraturan yang berlaku pada lingkungan kehidupan sosial masyarakat tersebut, untuk memenuhi kebutuhan sosial masyarakat ataupun orang/ pribadi yang semakin hari semakin meningkat maka masyarakat semakin banyak melakukan hubungan kerja sama untuk mengikatkan dirinya dalam suatu perjanjian dengananggota masyarakat lainnya dalam usaha pemenuhan kebutuhan hidupnya, sehingga memungkinkan terjadinya berbagai macam perjanjian-perjanjian yang dilakukan oleh masyarakat salah satunya adalah perjanjian sewa-menyewa. Perjanjian sewa menyewa merupakan salah satu perjanjian yang dibuat antara pemilik barang atau pemilik jasa untuk diberikan kepada pihak lain dengan waktu yang ditentukan sesuai dengan isi kesepakatan diantara kedua belah pihak, sewa menyewa yang melibatkan pihak yang memerlukan Rumah Toko dan pihak yang menyewa.

Dengan adanya kesepakatan yang dilakukan oleh kedua belah pihak menimbulkan kewajiban-kewajiban yang harus dipenuhi oleh masing-masing pihak, salah satu keutungan dari masing-masing pihak dalam melaksankan perjanjian sewamenyewa adalah menimbulkan kejelasan bagi kedua belah pihak untuk melaksanakan isi dari perjanjian sewa-menyewa tersebut. Kebutuhan akan ruko tersebut menjadi salah satu lahan bisnis atau usaha bagi masyarakat yang memiliki tanah atau rumah ditempat yang strategis untuk membangun ruko yang khusus disewakan kepada pelaku usaha dagang maupun perkantoran. Adanya keadaan yang demikian menyebabkan timbulnya perjanjian sewa menyewa ruko. Kesepakatan merupakan hal yang sangat penting karena terikatnya suatu perjanjian setelah tercapainya kata sepakat. Dalam suatu perjanjian diharuskan pertemuan kemauan yang dikehendaki oleh para pihak terhadap hal-hal yang pokok dari perjanjian itu. Sejak tercapainya kata sepakat tentang suatu hal yang diperjanjikan, maka sejak itu pula lahir hubungan hukum antara para pihak yang membuat perjanjian tersebut 
dan masing-masing pihak terikat satu sama lainnya, sehingga menimbulkan hak kewajiban bagi mereka. Pengertian tanggung jawab dalam Kamus Umum Bahasa Besar Indonesia adalah keadaan dimana wajib menanggung segala sesuatu, sehingga berkewajiban menanggung, memikul jawab, menanggung segala sesuatunya atau memberikan jawab dan menanggung akibatnya. Setiap hubungan hukum akan mempunyai akibat hukum, dalam arti menimbulkan adanya hak dan kewajiban bagi kedua belah pihak yang mengadakan hubungan hukum. Demikian juga halnya dengan perjanjian sewa menyewa, akan menimbulkan hak dan kewajiban bagi kedua belah pihak, yaitu antara pihak pemilik barang dengan pihak penyewa. Hal ini dikarenakan hak dan kewajiban itu merupakan suatu perbuatan yang bertimbal balik, artinya hak dari satu pihak merupakan kewajiban dari pihak lain, begitu juga dengan sebaliknya.

\section{METODE PENELITIAN}

Menurut pendapat Soemitro "setiap penelitian haruslah disertai dengan pemikiranpemikiran teoritis. Berdasarkan pendapat Soemitro diatas maka yang menjadi landasan pemikiran bagi Peneliti adalah Perjanjian, Sewa menyewa dan Ruko. Metode pendekatan yang digunakan oleh peneliti dalam penelitian ini adalah Metode Yuridis Sosiologis yaitu pendekatan masalah melalui penelitian hukum dengan fakta yang ada pada instansi yang bersangkutan ataupun masyarakat sehubungan dengan permasalahan yang ditemui dalam penelitian $^{1}$. Sifat penelitian ini adalah Deskriptif Analisis, yaitu suatu penelitian yang menggambarkan secara menyeluruh dari sistematis obyek dari pokok permasalahan. ${ }^{2}$ Dengan adanya penelitian Deskriptif analisis merupakan penelitian yang menggambarkan dan menguraikan keadaan maupun fakta yang ada secara jelas diuraikan secara sistematis atas perjanjian sewa-menyewa berdasarkan Kitab Undang-Undang Hukum Perdata.

Pengumpulan data merupakansuatu tahapan dalam proses penelitian ini dan sifatnya mutlak untuk dilakukan karena data merupakan fenomena yang akan diteliti. Data yang dipergunakan dalam penelitian ini adalah data primer dan data sekunder. Untuk memperoleh gambaran tentang fenomena yang diteliti hingga penarikan suatu kesimpulan, maka peneliti tidak mungkin terlepas dari kebutuhan suatu data yang valid. Dalam penelitian ini peneliti mengambil populasi dan sampel dalam menjawab dan menganalisa persoal hukum yang ada kaitannya dengan persoalan yang diangkat dimana Populasi adalah keseluruhan objek penelitian dengan ciri sama. Populasi dapat berupa orang, benda, kejadian kasus-kasus, waktu dan tempat, dengan sifat atau ciri sama. ${ }^{3}$. untuk itu peneliti

1 Soerjono Soekanto, Pengantar Penelitian Hukum, universitas Indonesia, Jakarta, 2006

2 Bambang Waluyo, Penelitian Hukum Dalam Praktek, Jakarta, sinar grafika, 1991 hal: 122 
dalam penelitian ini mengambil populasi yaitu seluruh pasangan yang melaksanakan perjanjian sewa-menyewa Ruko di Kabupaten Melawi.

Sampel adalah merupakan bagian dari populasi, yang menjadi sumber data dalam penelitian ini. Adapun teknik pengambilan sampel dalam penelitian proposal ini adalah menggunakan bentuk Purposive Sampling (sampel bertujuan), yaitu memilih orangorang tertentu karena dianggap mewakili populasi, sebagaimana dikatakan Hadari Nawawi tentang Purposive sampling adalah "Dalam teknik ini pengambilan sampel disesuaikan dengan tujuan penelitian. Ukuran sampel tidak dipersoalkan sebagaimana didalam accidental sampling. Perbedaannya terletak pada pembatasan sampel dengan hanya mengambil unit sampling yang sesuai dengan tujuan penelitian. Dengan kata lain unit sampel yang dihubungi sesuai dengan kriteria-kriteria tertentu yang ditetapkan berdasarkan tujuan penelitian. ${ }^{4}$ Sehubungan dengan itu, maka dalam penelitian ini penulis telah mengambil sampel Pemilik Ruko yang disewakan dan orang Penyewa Ruko.

Teknik analisa data adalah suatu metode atau cara untuk memecahkan suatu masalah atau mengkaji suatu hipotesis, berdasarkan data yang telah dikumpulkan dan pada akhirnya diinterpretasikan untuk tan Hukum, P.T raja Grafindo, Persada, Jakarta 2005, hal : 118

$4 \quad$ Hadari Nawawi, Metode Penelitian Bidang Sosial, Gajah Mada University Press, Yokyakarta, 2007, hal : 167 menjawab suatu masalah. Dalam penelitian ini analisis data yang dipergunakan analisis kualitatif adalah suatu cara penelitian yang menghasilkan data deskriptif analitis yaitu yang dinyatakan oleh responden secara tertulis atau lisan serta tingkah laku yang nyata, yang diteliti dan dipelajari sebagai Sesuatu yang utuh. Peneliti dalam melakukan penelitian ini akan melakukan penelitian di Kota Pinoh Kabupaten Melawi.

\section{PEMBAHASAN}

Kabupaten Melawi adalah sebuah kabupaten di provinsi Kalimantan Barat. Kabupaten Melawi memiliki tiga sungai membentang di wilayah tersebut di antaranya, yaitu Sungai Kayan, Sungai Melawi dan Sungai Pinoh. Dahulu dikenal sebagai daerah Melawei (alias Laway, Melahoei., Pinoe). Daerah aliran sungai Pinoh merupakan termasuk wilayah Kerajaan Kotawaringin. Kontrak 1756, Sultan Tamjidullah Idari Banjarmasin dengan VOC-Belanda mendaftarkan Melawai (alias Melawi) dalam wilayah pengaruh Kesultanan Banjarmasin. Tanggal 1 Januari 1817 Raja Banjar Sultan Sulaiman menyerahkan Sintang dan Melawi (disebut dengan nama Lawai) kepada Hindia Belanda. Tanggal 4 Mei 1826, Sultan Adam dari Banjarmasin menyerahkan Lawai (alias Melawi) kepada Hindia Belanda.

Kabupaten Melawi merupakan salah satu kabupaten baru yang baru terbentuk 
melalui tahapan pemekaran dari Kabupaten Sintang. Berdasarkan Surat Menteri Dalam Negeri Nomor 135/1213/SJ tanggal 21 Mei 2004 Perihal Pedoman Teknis Pelaksanaan 13 (tiga belas) Undang-undang tentang pembentukan 24(duapuluhempat) Kabupaten, di mana Kabupaten Melawi merupakan salah satu dari 24 Kabupaten baru yang dibentuk oleh Pemerintah.

Dasar Pembentukan Kabupaten Melawi adalah Undang-undang Republik Indonesia Nomor 34 tahun 2003 Tentang Pembentukan Kabupaten Melawi dan Kabupaten Sekadau di Provinsi Kalimantan Barat. Peresmian Kabupaten Melawi bersamasama 23 (dua puluh tiga) Kabupaten lainnya dan 13 (tiga belas) Propinsi dilakukan oleh Menteri Dalam Negeri pada tanggal 7 Januari 2004 di Jakarta.

Pembentukan Kabupaten Melawi tersebut bertujuan untuk mewujudkan aspirasi masyarakat yang berkembang di Kabupaten Sintang untuk meningkatkan pelayanan kepada masyarakat di bidang pemerintahan, pembangunan dan kemasyarakatan. Guna menunjang tugas-tugas pokok pemerintahan, pembangunan dan kemasyarakatan dimaksud, ditetapkanlah Penjabat Bupati Melawi pertama melalui Keputusan Menteri Dalam Negeri Nomor 131.41-16 tahun 2003 Tentang Pengangkatan Penjabat Bupati Melawi atas nama Drs. A. SUMAN KURIK, MM yang dilantik pada tanggal 14 Januari 2004 oleh
Gubernur Kalimantan Barat. Untuk pertama kalinya Penjabat Bupati Melawi dibantu oleh 9 (sembilan) orang Pegawai Negeri Sipil berdasarkan Surat Tugas Bupati Sintang nomor 824/045/BKD-C tanggal 20 Januari 2004.

Dilihat dari letak geografisnya, Kabupaten Melawi terletak diantara $0^{\circ} 07$ ? LS $1^{\circ} 21$ ? LS serta $111^{\circ} 07$ ? BT dan $112^{\circ} 27$ ? BT, dengan batas-batas wilayah sebagai berikut, Sebelah Utara berbatasan dengan Kabupaten Sintang, Sebelah Selatan berbatasan dengan Propinsi Kalimantan Tengah, Sebelah Timur berbatasan dengan Kabupaten Sintang dan Sebelah Barat berbatasan dengan Kabupaten Ketapang. Pada awal berdirinya, Kabupaten Melawi terdiri dari 7 kecamatan, 82 desa dan 292 dusun, yang kemudian dilakukan pemekaran beberapa kecamatan baru yang dibentuk berdasarkan Perda Nomor. 32 Tahun 2007 Tentang Pembentukan KecamatanPinoh Utara, Kecamatan Pinoh Selatan, Kecamatan Belimbing Hulu dan Kecamatan Tanah Pinoh Barat, sehingga sekarang ini Kabupaten Melawi terdiri dari 11 kecamatan, 169 desa dan 525 dusun, dimana kecamatan terluas adalah Kecamatan Sokan dengan luas 1.577,2 $\mathrm{km}^{2}$ atau $14,83 \%$ dari luas KabupatenMelawi $\left(10.640,8 \mathrm{~km}^{2}\right)$, sedangkan kecamatanterkecil adalah Kecamatan Belimbing Hulu dengan luas 454,0 $\mathrm{km}^{2}$ atau 4,27 \% dari luas Kabupaten Melawi. 


\section{LUAS WILAYAH KABUPATEN}

\section{MELAWI}

\begin{tabular}{|c|c|c|c|c|}
\hline No & Kecamatan & Ibukota & $\begin{array}{l}\text { Luas } \\
\left(\mathbf{K m}^{2}\right)\end{array}$ & $\begin{array}{c}\text { Persentase } \\
\text { Terhadap } \\
\text { Luas Kab. }\end{array}$ \\
\hline 1. & Sok a n & $\begin{array}{l}\text { Nanga } \\
\text { Sokan }\end{array}$ & $1.577,2$ & $14,82 \%$ \\
\hline 2. & Tanah Pinoh & Kota Baru & 739,3 & $6,95 \%$ \\
\hline 3. & $\begin{array}{c}\text { Tanah Pinoh } \\
\text { Barat }\end{array}$ & Ulak Muid & 829,0 & $7,79 \%$ \\
\hline 4. & $\mathrm{~S}$ a y a $\mathrm{n}$ & $\begin{array}{l}\text { Nanga } \\
\text { Sayan }\end{array}$ & $1.166,3$ & $10,96 \%$ \\
\hline 5. & Belimbing & Pemuar & $1.238,0$ & $11,63 \%$ \\
\hline 6. & $\begin{array}{c}\text { Belimbing } \\
\text { Hulu } \\
\end{array}$ & $\begin{array}{c}\text { Tiong } \\
\text { Keranjik } \\
\end{array}$ & 454,0 & $4,27 \%$ \\
\hline 7. & $\begin{array}{l}\text { Nanga } \\
\text { Pinoh } \\
\end{array}$ & $\begin{array}{l}\text { Nanga } \\
\text { Pinoh }\end{array}$ & 617,2 & $5,80 \%$ \\
\hline 8. & $\begin{array}{l}\text { Pinoh } \\
\text { Selatan }\end{array}$ & Manggala & 931,0 & $8,75 \%$ \\
\hline 9. & Pinoh Utara & Tekelak & 890,0 & $8,36 \%$ \\
\hline 10. & Ella Hilir & $\begin{array}{c}\text { Nanga } \\
\text { Ella Hilir } \\
\end{array}$ & $1.136,7$ & $10,71 \%$ \\
\hline 11. & Menukung & $\begin{array}{c}\text { Menukung } \\
\text { Kota }\end{array}$ & $1.062,1$ & $9,98 \%$ \\
\hline & $\begin{array}{c}\text { Total Luas } \\
\text { Wilayah }\end{array}$ & & $10.640,8$ & 100 \\
\hline
\end{tabular}

Sumber Data : Bappeda Kab.Melawi Tahun 2017

Perjanjian sewa-menyewa rumah toko dapat dibuat baik dihadapan notaris maupun dapat dibuat dibawah tangan. Perjanjian yang dapat dibuat dihadapan notaris disebut dengan akta otentik yang diatur dalam pasal 1869 KUH Perdata, akta otentik tersebut ialah suatu akta yang didalam bentuk yang ditentukan oleh undang-undang, dibuat oleh

atau dihadapan pegawai-pegawai umum yang berkuasa untuk itu tempat diman akta dibuatnya. Sedangkan perjanjian yang dibuat dibawah tangan yaitu akta dibawah tangan, dimana cara pembuatan atau terjadinya tidak dilakukan oleh dan atau dihadapan pejabat pegawai umum, akan tetapi hanya olehpihakpihak yang berkepentingan saja, salah satunya adalah perjanjian yang disepakati oleh kedua belah pihak yang berkepentingan.Berdasarkan hasil wawancara peneliti denganbapak Akhie Rusvianus Ekeh, S.Sos sebagai pemilik rumah toko sedangkan Bapak Agus Kurniadi sebagai penyewa Rumah toko menjelaskan bahwa surat perjanjian sewa menyewa rumah toko tersebut dibuat secara dibawah tangan dan ditanda tangani oleh kedua belah pihak bersama-sama dengan dua orang saksi, yang masing-masing pihak memiliki satu orang saksi. ${ }^{5}$ Dari penjelasan yang disampaikan oleh pemilik rumah toko maupun penyewa rumah toko ditinjau dariperjanjian yang dilakukan oleh kedua belah pihak berdasarkan pasal Ketentuan yang mengatur tentang perjanjian sewa menyewa terdapat dalam pasal 1548 KUHPerdata yang menyebutkan sewa menyewa adalah suatu perjanjian dengan mana pihak yang satu mengikatkan dirinya untuk memberikan kepada pihak lainnya kenikmatan dari suatu barang, selama suatu waktu tertentu dan dengan pembayaran sesuatu harga, yang oleh pihak tersebut belakangan itu disanggupi pembayarannya. Pelaksanaan perjanjian

\section{Hasil wawancara penulis tanggal} 25 januari 2021 dirumah Toko Sewa Bapak Agus Kurniadi dijalan Sidomulyo Kecamatan Nanga Pinoh Kabupaten Melawi 
sewa menyewa rumah toko oleh kedua belah pihak dimulai dari tahapan pra penyusunan perjanjian yakni adanya kesepakatan diantara kedua belah pihak secara lisan untuk mengadakan perjanjian sewa menyewa rumah toko yang beralamat dijalan Sidomulyo Kecamatan Nanga Pinoh Kabupaten Melawi. Dari hasil pertemuan dan kesepakatan tersebut maka dilakukanlah sebuah perjanjian kedalam tahapan penyusunan perjanjian, penyusunan isi dari perjanjian bagi kedua belah pihak sangatlah penting agar dapat dimengerti dan dipahami dalam penyusunan isi perjanjian yang akan dilakukan sebelum perjanjian tersebut dibuat.

Sebelum suatu perjanjian disusun,para pihak perlu memperhatikan hal-hal yang menyangkut catatan awal atau resume dari pembicaraan awal atau perundingan antara para pihak. Dalam penyusunan tahapantahapan pra perjanjian adalah sebagai berikut :

\section{Negosiasi}

Negosiasi merupakan sarana bagi para pihak untuk mengadakan komunikasi dan arah yang dirancang demi mencapai kesepakatan sebagai akibat adanya perbedaan pandangan atau tafsir terhadap suatu hal berkaitan dengan kerangka perjanjian.Saat negosiasi inilah masing-masing pihak menyampaikan penawaran terhadap yanglain sehingga tercapai kesepakatan. Demi suksesnya proses negosiasi maka bagi para pihak perlu persiapan yang matang yang menyangkut tentang bagaimana perjanjian tersebut dilaksnakan oleh kedua belah pihak.

2. Pembuatan Nota kesepakatan

Sebelum menyusun nota kesepakatan, para pihak perlu melakukan identifikasi diri apakah sudah memenuhi ketentuan undangundang, seperti caakap hukum, umur, tentang objek, dan tempat domisili yang jelas dari masing-masing pihak.

Setelah negosiasi selesai dilakukan tahapan pra perjanjian selanjutnya adalah membuat nota kesepakatan yang merupakan pencatatan atau penyusunan pokok-pokok persetujuan dari hasil negosiasi awal dalam bentuk tertulis. Walaupun belum merupakan suatu perjanjian nota kesepakatan mempunyai pesan sebagai pegangan untuk melakukan negosiasi lanjutan atau sebagai dasar pembuatan perjanjian.

Berdasarkan hasil wawancara dengan bapak Agus Kurnadi sebgai pihak penyewa Rumah Ruko mengatakan bahwa penawaran yang dilakukan oleh Bapak Akhie sebagai pemilik Rumah Toko sebesar Rp. 30.000.000,(tiga puluh juta rupiah) dalam jangka waktu satu tahun dan disetuji, maka pada tanggal 27 Desember 2015 surat perjanjian dibuat antara kedua belah pihak. ${ }^{6}$

Sebagaimana dalam perjanjiansetelah adanya kesepakatan-kesepakatan

dalam negosiasi awal maka langkah-langkah 6 Hasil wawancara peneliti tanggal 25 januari 2021 dirumah Toko Sewa Bapak Agus Kurniadi dijalan Sidomulyo Kecamatan Nanga Pinoh Kabupaten Melawi 
selanjutnya adalah membuat surat perjanjian.

Sebelum surat perjanjian dibuat dan ditanda tangani oleh kedua belah pihak maka hasil negosiasi harus sudah bersifat final dan hasil identifikasi diri kedua belah pihak sudah memenuhi ketentuan perundang-undangan. Tahapan penyusunan perjanjian memerlukan ketelitian dan kejelian dari para pihak dan maupun notaris atau pejabat lainnya. Karena apabila keliru merumuskan nama dan data poko, maka perjanjian akan menimbulkan kesulitan dalam pelaksanaannya dikemudian hari. Pada umumnya dikenal dengan lima fase penyusunan perjanjian di Indonesia sebagai berikut:

1. Membuat konsep (draf) pertama prosesnya meliputi diantaranya adalah :

a. Judul Perjanjian: dalam judul perjanjian harus diperhatikan kecocokan isi dengan judulperjanjian serta acuan hukum yang mengikatnya. Hal ini dilakukan untuk menghindari kesalahpahaman dikemudian hari.

b. Pembukaan : pembukaan biasanya berisi tanggal pembuatan perjanjian.

c. Pihak-pihak (para pihak) dalam perjanjian : para pihak menjelaskan identitasnya secara lengkap dengan menyebutkan nama, pekerjaanatau jabatan, tempat tanggal, kewarganegaraan dan bertindak atas nama siapa. d. Latar belakang kesepakatan: berisi penjelasan resmi tentang latar belakang terjadinya suatu kesepakatan.

e. Isi Perjanjian : bagian yang merupakan inti perjanjian, yang memuat apa yang dikehendaki hak dan kewajiban termasuk [ilihan penyelesaian semgketa. Pada bagian inti dari sebuah perjanjian diuraikan secara rinci isi perjanjian yang biasanya dibuat dalam pasal-pasal ayat-ayat, huruf-huruf dan angkaangka.

f. Penutup : Jika semua hyal yang diperlukan telkah tercantum dalam bagian isi perjanjian, barulah dirumuskan bagian penutup perjanjian. Penutup memuat tata cara pengesahan suatu perjanjian.

2. Saling menukar konsep atau draf perjanjian, dengan cara ini setiap pihak yang melakukan perjanjian dapat mengkaji ulang atau membuat konsep akhir tersebut untuk diformalkan secara hukum.

3. Lakukan revisi (apa bila diperlukan). Hal ini ditempuh apabila ada msalah yang belum jelas, atau terjadi perubahan situasi atau adanya bencana alam.

4. Melakukan penyelesaian akhir

5. menandatangani perjanjian oleh masigmasing pihak.

Untuk memahami perjanjian 
Stefanus Ngebi, Wanprestasi Perjanjian Rumah Toko 31

secara sempurna ada baiknya para pihak mengetahui bagaimana konsep dasar atau struktur perjanjian beikut unsur-unsir pokok yang harus ada yang disebut anatonim perjanjian. Pada dasarnya susunan dan anatonim perjanjian dapat dikelompokan menjadi tiga bagian yaitu pendahuluan, isi dan penutup.

Berikut ini uraian susunan pada surat prjanjian sewa menyewa rumah toko pada Surat perjanjian Sewa menyewa Ruko :

1. Pada bagian pendahuluan : memuat secara lengkap semua hal seperti nama perjanjian sewa menyewa, selanjutnya perjanjian memuat identitas lengkap para pihak yang mengikatkan diri dalam sebuah perjanjian dan siapa yang menandatangani perjanjian tersebut adalah sebagai berikut :

a. Nama : $\mathrm{A} \mathrm{k} \mathrm{h} \mathrm{i} \mathrm{e}$

Rusvianus Ekeh

Tempat/ tgl lahir : Tontang 09 Januari 1969

Pekerjaan : wiraswasta

Alamat : D

Niagakarya RT/RW/ 001/001 Dsm

Tanjung Niaga

$\mathrm{Kec}$

Nanga Pinoh

Kabupaten

Melawi :6xxxxxxxxxxxxxxx

Dalam hal ini bertindak atas nama pribadi yang selanjutnya disebut pihak pertama.

b. Nama : Agus Kurnadi

Tempat Tgl Lahir : Sekadau 27 Juli 1978

Pekerjaan : Karyawan Swasta

Alamat : Dsn Pemda Ko,p Bumi Rt/ Rw 003/003 Citra Saigon Kec Pontianak Timur Kab pontianak Kalimantan Barat

No Idenitas

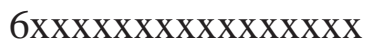

Dalam hal ini bertindak atas nama pribadi yang selanjutnya disebut pihak kedua

Berdasarkan kan hasil penelitian peneliti dengan Bapak Agus Kurnadi sebagai penyewa ruko menyampaikan bahwa dalam perjanjian sewa menyewa rumah toko terdapat 6 pasal yang terdiri dari

a. Pasal 1 menerangkan tentang jumlah penyewaan Rumah toko yang harus dibayar oleh pihak kedua

b. Pasal 2 menerangkan hak dan kewajiban bagi pihak kedua diantaranya adalah termasuk penggunaan fasilitas Ruko serta kewajiban untuk membayar tagihan listrik

c. Pasal 3 menerangkan tentang pihak 
kedua berhak bertanggungjawab tentang berlakunya peraturanperaturan daerah yang menyangkut retribusi pajak dan berkewajiban untuk keamanan rumah toko yang disewa.

d. Pasal 4 menerangkan tentang berakhirnya surat perjanjian sewa menyewa rumah toko maka harus dikosongkan dan menyerahkan kemabali kepada pihak peratama,

e. Pasal 5 menjelaskan apabila terjadi perselisihan dalam perjanjian sewa menyewa maka kedua belah pihak akan melakukan musyawarah terlebih dahulu sebelum menempuh upaya hukum dipengadilan.

f. Pasal 6 menjelaskana tentang waktu dan tempat dimana perjanjian sewa menyewa dilaksanakan. ${ }^{7}$

Berdasarkan hasil penelitian yang dilakukan oleh peneliti terhadap pemilik rumah toko yang menyewakan bapak Akhie mengatakan bahwa, sebelum menyewakan rumah toko kepada penyewa dilakukan beberapa hal salah satunya adalah dengan memasang sepanduk penawaran kepada masyarakat yang melintas. Apabila ada yang berminat maka dilakukan negosiasi kesepakatan

$7 \quad$ Hasil wawancara peneliti tanggal 25 januari 2021 dirumah Toko Sewa Bapak Agus Kurniadi dijalan Sidomulyo Kecamatan Nanga Pinoh Kabupaten Melawi secara lisan terlebih dahulu selanjutnya baru akan dilakukan perjanjian secara bersama-sama. ${ }^{8}$

Dengan melihat perjanjian yang dilakukan oleh para pihak diatas berdasarkan pasal 1313 KUHPerdata, bahwa perjanjian adalah suatu perbuatan hukum ketika seseorang atau lebih mengikatkan dirinya terhadap seorang atau lebih. Perjanjian juga dapat diartikan ketika seseorang berjanji kepada orang lain, atau ketika 2 (dua) orang saling berjanji untuk melaksanakan suatu perbuatan. Perjanjian dengan demikian mengikat para pihak secara hukum, untuk mendapatkan hak dan kewajiban yang ditentukan dalam perjanjian itu.

Perjanjian sewa menyewa rumahtoko yang dilakukan mulai dari penawaran harga, sampai pada fasilitas bangunan rumah toko akan disampaikan kepada pihak penyewa,agar selam penyewaan yang dilakukan oleh masyarakat tidak merasa kecewa, apa lagi pada saat sekarang ini sudah bermunculan bangunan-bangunan disepanjang jalan Nanga Pinoh. ${ }^{9}$

Berkaitan dengan perjanjian sewa menyewa ruko berdasarkan ketentuan Pasal 1570 dan pasal 1571 KUHPerdata. Bunyi Pasal 1570 KUHPerdata ialah: Jika sewa dibuat dengan tulisan, maka sewa itu berkahir demi hukum, apabila waktu yang ditentukan 8 Hasil wawancara peneliti tanggal26 januari 2021 dirumah kediaman Bapak Akhie dsn Tanjung Niaga Kecamatan Nanga Pinoh Kabupaten Melawi

9 ibid 
telah lampau, tanpa diperlukannya sesuatu pemberutahuan untuk itu. Sedangkan bunyi Pasal 1571 KUHPerdata: Jika sewa tidak dibuat tulisan, maka sewa itu tidak berakhir pada waktu yang ditentukan, melainkan jika pihak lain memberitahukan bahwa ia hendak menghentikan sewanya, dengan mengindahkan tenggang-tenggang waktu yang diharuskan menurut kebiasan setempat.

Salah satu aspek yang sangatpenting dalam perjanjian adalah pelaksanaan perjanjian itu sendiri. Pelaksanaan perjanjian inilah yang menjadi tujuan orang-orang yang mengadakan perjanjian. Setiap pihak dalam hal ini kreditur maupun debitur yang membuat perjanjian menghendaki agar pelaksanaan perjanjian diusahakan dengan sempurna agar dalam perjanjian dikemudian hari tidak terjadi perselisihan diantara kedua belah pihak.

Berdasarkan hasil wawancara peneliti dengan Bapak Akhie yang mempunyai beberapa rumah toko disewakan di Kota pinoh mengatakan bahwa perjanjian kalau dilihat dari bentuk dan wujudnya merupakan rangkaian kata-kata dan kalimat yang mengandungjanji-janji ataupun kesanggupankesanggupanyang diucapkan dan dituangkan dalam bentuk tulisan oleh pihak-pihak baik pihak penyewa maupun pihak yang menyewakan dengan membuat perjanjian. ${ }^{10}$

Dalam isi perjanjian tercantum

10 Hasil wawancara peneliti tanggal26 januari 2021 dirumah kediaman Bapak Akhie dsn Tanjung Niaga Kecamatan Nanga Pinoh Kabupaten Melawi didalamnya hak-hak dari kedua belah pihak serta kewajiban-kewajiban yang dilakukan oleh para pihak berdasarkan hasil wawancara penulis dengan penyewa rumah toko bapak Agus Kurnadi mengatakan bahwa kewajiab bagi penyewa rumah toko adalah membayar besarnya penyewaan dilakukan serta kewajiban selama penyewa mendiamai bangunan rumah toko, salah satunya adalah merawat bangunan, membayar retribusi pada pihak pemerintah kabupaten, serta menjaga rumah toko dalam kondisi sedia kala apabila kontrak perjanjian tersebut sudah dinyatakan selesai. ${ }^{11}$

Berdasarkan Hasil wawancara peneliti dengan Bapak Akhie yang menyewakan rumah toko meenyampaikan bahw salah satu kewajiban bagi pemilik rumah toko adalah menyediakan fasilitas bangunan salah satunya adalah listrik, air, kondisi bangunan tidak bocor, serta fasilitas penunjang lainnya sepertiakses parkir didepan bangunman. Sementara hak dari pemilik bangunan rumah toko adalah menerima pembayaran dari penyewa, serta penyewa apabila sudah meninggalkan atau kontrak sudah selesai maka banguna dalam kondisi seperti sediakala pada saat penyewa baru datang untuk mengontrak. ${ }^{12}$

Dari keterangan-keterangan yang

11 Hasil wawancara peneliti tanggal 25 januari 2021 dirumah Toko Sewa Bapak Agus Kurniadi dijalan Sidomulyo Kecamatan Nanga Pinoh Kabupaten Melawi

12 Hasil wawancara peneliti tanggal26 januari 2021 dirumah kediaman Bapak Akhie dsn Tanjung Niaga Kecamatan Nanga Pinoh Kabupaten Melawi 
disampaikan oleh nara sumber diatas dapat penulis samapaikan bahwa kewajibankewajiban bagi para pihak adalah dalam perjanjian tersebut sudah melaksanakan perjanjian sesuai dengan isi kesepakatanyang dilakukan. Dalam setiap perjanjian yang dilakukan oleh pihak-pihak merupakan aturan yang harus diikuti dan sebagai undang-undang bagi kedua belah pihak yang membuat perjanjian oleh sebab itu apabiila salah satu pihak dinyatakan lalai dalam memenuhi prestasinya maka pihak yang merasa dirugikan dapat menuntut dari isi perjanjian tersebut.

Berkaitan dengan pengertian perjanjian tentang kewajiban-kewajiban para pihak diatas maka berikut ini perjanjian berdasarkan pendapat ahli Menurut Prof. Purwahid Patrik yang menyatakan bahwa perjanjian adalah perbuatan yang terjadi sesuai dengan formalitas-formalitas dari peraturan hukum yang ada tergantung dari persesuaian kehendak dua atau lebih orangorang yang ditujukan untuk timbulnya akibat hukum dari kepentingan salah satu pihak atas beban pihak lain atau demi kepentingan masing-masing pihak secara timbal balik. Menurut Van Dunne, yang diartikan dengan perjanjian adalah :"suatu hubungan hukum antara dua pihak atau lebih berdasarkan kata sepakat untuk menimbulkan akibat hukum. ${ }^{13}$

Menurut Abdul Kadir Muhammad dalam bukunya yang berjudul Hukum 13 Salim, 2002, Pengantar Hukum Perdata Tertulis (BW), (Jakarta: Sinar Grafika, hlm 160 perikatan yang di maksud dengan perjanjian adalah:"persetujuan antara dua orang atau lebih dengan saling mengikatkan diri untuk melaksanakan suatu hal mengenai harta kekayaan Pada Pasal 1321 KUHPerdata ditentukan bahwa tiada sepakat yang sah ataupun sepakatitu diberikan karenakekhilafan atau diperoleh dengan paksaan ataupunn penipuan. Sepakat yang dimaksudkan adalah persetujuan kehendak yang terjadi antara para pihak, tanpa adanya unsur paksaan, penipuan dan kekhilafan. ${ }^{14}$

Adanya perjanjian yang dibuatmaka lahirlah perikatan yakni, dalam bahasa Belanda perikaatan disebut dengan verbintenis. Perikatan merupakan terjemahan dari verbintenis atau verbinden, yang artinya mengikat. Istilah verbintenis menunjuk pada adanya "ikatan" atau "hubungan" sehingga verbintenis diartikan sebagai suatu hubungan. ${ }^{15}$ Berdasarkan Hasil wawancara dengan Bapak Akhie selaku pemilik rumah toko menyampaikan bawha apabila penyewa dalam hal ini bapak Agus Kurniadi membatalkan perjanjian yang sudah berjalan beberapa bulan apakah pihak pemilik rumah toko akan mengembalikan sisa dari uang sewa tersebut kepada penyewa. Pihak penyewa dalam perjanjian atau kesepakatan dilakukan bahwa dari awal penyewaan adalah jangka waktu satu tahun dan apabila pihak penyewa membatalkan ditengah jalan artinya tidak 14 Wawan Muhwan Hariri, 2011, Hukum Perikatan, (Bandung: Pustaka Setia), hlm 121

15 ibid hal 15 
sampai satu tahun maka uang yang diberikan tidak dapat dikembalikan, karena anggapan dari penyewa rumah toko bawha penyewa sudah menyewa rumah toko dalam waktu satu tahun, apabila penyewa mengambil jangka waktu perbualan maka surat perjanjian yang dibuat harus ditinjau uilang kembali. ${ }^{16}$

Berdasarkan hasil wawancara peneliti dengan Bapak Agus Kurnadi menyampaikan apabila terjadi pembatalan perjanjian dilakukan di pertengahan tahun berjalan apakah resiko yang didapati oleh penyewa. Dalam kaitan perjanjian sewa menyewa atau kontrak bangunan resiko apabila membatalkan dari perjanjian yaitu uang yang sudah diberikan kepada pemilik bangunan akan dianggap hangus atau tidak dapat diambil kembali kecuali terjadi kesepakatan ulang, itupun harus ada alasan yang mendasar, karena pada dasarnya setiap kesepakatan yang dilakukan oleh pihak-pihak ingin kesepakatan tersebut berjalan sesuai dengan harapan.

\footnotetext{
Berdasarkan hasil wawancara peneliti dengan para narasumber diatas bahwa perjanjian yang dilakukan oleh pihakpihak tersebut menginginkan agar perjanjian berjalan sesuai dengan yang diinginkan dan segala resiko yang terjadi dapat terhindarkan, oleh sebab itu perjanjian sewa-menyewa ruko yang terjadi antara para pihak dalam

16 Hasil wawancara peneliti tanggal 26 januari 2021 dirumah kedia- man Bapak Akhie dsn Tanjung Niaga Kecamatan Nanga Pinoh Kabupaten Melawi
}

hal ini dalam objek pembayaran sewa ruko seharusnya dapat berjalan sesuai dengan yang dinginkan apabila masing-masing para pihak dapat menjalankan kewajibannya.

\section{SIMPULAN}

Berdasarkan uraian-uraian diatas maka dapat peneliti simpulkan dalam penelitian ini Bahwa pelaksanaan perjanjian sewa menyewa rumah toko antara yang menyewakan dengan pihak penyewa di Jalan Sido Mulyo Kecamatan Nanga Pinoh Kabupaten Melawi telah dilaksanakan sesuai dengan tahapan-tahapan yang dilakukan oleh para pihak mulai dari negosiasi sampai dengan penandatangan surat perjanjian dan bahwa tanggungjawab bagi para pihak dalam melaksankan perjanjian sesuai dengan kesepakatan yang dilaksanakan sewa menyewa rumah toko dijalan Sidomulyo Kecamatan Nanga pinoh kabupaten Melawi dalam setiap pembatalan perjanjian maka resiko dari sewa menyewa tersdebut menjadi tanggung jawab si penyewa apabila dibatalkan. Selain itu tentu peneliti juga memberikan saran berdasarkan pada simpulan diatas Agar pelaksanaan sewa menyewa rumah toko antara pihak yang menyewakan dengan pihak yang menyewa di Kecamatan Nanga Pinoh Kabupaten Melawi dilaksanakan dengan itikat baik berdasarkan hak dan kewajiban yang melekat pada masingmasing pihak serta dalam isi perjanjian diatur terlebih dahulu serta ikutsertakan sanksi dari 
masing-masing pihak jika terjadi kelalaian dalam menepati isi perjanjian secara legal formal memberikan kemudahan dalam penyelesaiannya. Sselain itu diharapkan agar perumusan isi perjanjian dilakukan secara rinci dan tegas sehingga tanggung jawab para pihak dalam memenuhi hak dan kewajiban masing-masing pihak dapat dengan segera terpenuhi.

\section{SARAN}

Selayaknya perjanjian itu dilakukan dengan itikat baik berdasarkan hak dan kewajiban yang melekat pada masingmasing pihak serta dalam isi perjanjian diatur terlebih dahulu serta ikutsertakan sanksi dari masing-masing pihak jika terjadi kelalaian dalam menepati isi perjanjian secara legal formal memberikan kemudahan dalam penyelesaiannya. Sselain itu diharapkan agar perumusan isi perjanjian dilakukan secara rinci dan tegas sehingga tanggung jawab para pihak dalam memenuhi hak dan kewajiban masing-masing pihak dapat dengan segera terpenuhi.

\section{DAFTAR PUSTAKA}

\section{REFENSI BUKU-BUKU}

Ali, Achmad, 2002, Menguak Tabir Hukum (Suatu Kajian Filosofis Dan Sosiologis),

Jakarta: Penerbit Toko Gunung Agung.
Anwar, Syamsul, 2010, Hukum Perjanjian Syariah, Jakarta : PT Rajagrafindo Persda.

Bungin, Burhan, 2003,Analisis Data Penelitian Kualitatif, Jakarta: PT. Raja Grafindo Persada.

Darus, Mariam, 2005, KUH Perdata Buku III Hukum Perikiitan Dengan Penjelasan, PT. Alumi Bandung.

Harahap, M. Yahya, 1986, Segi-Segi Hukum Perjanjian,Bandung: Alumni

Hariri, Wawan Muhwan, 2011, Hukum Perikatan, Bandung: Pustaka Setia.

Hay, Marhainis Abdul, 1984,Hukum Perdata Material, Jilid II, Cet-4, Jakarta: Pradnya Paramita.

Ichsan, Ahmad, 1982, Hukum Perdata IB, IP. Pembimbing Masa, Bandung.

Ronny Hanitijo Soemitro, 1983 Metode Penelitian Hukum, Jakarta, Ghalia Indonesia

R. Setiawan, 1999 PokokPokokHukumPerjanjian, (cet. 6, Jakarta: Putra Abadin Soemitro, Ronny Hanitijo, 1990, Metodologi Penelitian Hukum dan jurimetri, Jakarta Ghalia Indonesia.

Soerjono Soekanto, 2006, Pengantar Penelitian Hukum, Universitas Indonesia, Jakarta

Sudarsono, 2007 Kamus Hukum, Jakarta: Rincka Cipta 
http://www.landasanteori.

$\underline{\mathrm{com} / 2015 / 10 /}$

pengertian-perjanjian-

sewa-menyewa. html

diunduh pada tanggal 16

Januari 2021 jam 22.00

WIB

https://www.kompasiana.c

om/nopalmtq/

$\underline{\text { mengenal-arti- }}$

kata-tanggung

jawab 5529e68b6ea8

$\underline{342572552 \mathrm{~d} 24}$ diakses

hari selasa tanggal 16

Januari 2021 jam 15.30

wib 